\title{
MANAJEMEN PENDIDIKAN KARAKTER \\ DALAM MEWUJUDKAN GENERASI BERAKHLAKUL KARIMAH \\ DI SMP NEGERI 4 PURWOREJO
}

Dukhri Muhamad

(SMP Negeri 2 Purworejo)

dukhri@gmail.com

\begin{abstract}
ABSTRAK
Penelitian ini didasari oleh pentingnya akhlakul karimah. Sehubungan dengan hal tersebut, penelitian ini bertujuan untuk mengetahui Manajemen Pendidikan Karakter dalam Mewujudkan Generasi Berakhlakul Karimah di SMP Negeri 4 Purworejo. Penelitian ini merupakan penelitian kualitatif. Pengumpulan data menggunakan wawancara, observasi, dan dokumentasi, dan keabsahan data menggunakan triangulasi, dan teknik analisis data meliputi reduksi data, penyajian data, dan penarikan kesimpulan. Hasil penelitian ini menunjukkan bahwa: (1) Penanaman nilai-nilai dan moralitas dalam mewujudkan generasi berakhlakul karimah di SMP Negeri 4 Purworejo dilakukan oleh kepala sekolah, guru dan karyawan dan seluruh warga sekolah. Guru mengintegrasikan karakter melalui RPP pembelajaran dan melalui kegiatan ektra kurikuler sekolah, pemberian motivasi. (2) Pemodelan Nilai-Nilai dan Moralitas dalam Mewujudkan Generasi Berakhlakul Karimah dilakukan oleh kepala sekolah semua guru dan karyawan serta orang tua. Mereka menyadari bahwa perilakunya menjadi model bagi anak didiknya. Oleh karena itu semua warga sekolah senantiasa berhati hati dalam bertingkah laku dan bertutur kata dihadapan Peserta didik di sekolah. (3) SMP Negeri 4 Purworejo memfasilitasi nilai-nilai dan moralitas dalam mewujudkan generasi berakhlakul karimah. Sekolah memberikan kesempatan peserta didik untuk mengatasi masalah berkaitan dengan kegiatan sekolah. Kepala sekolah, guru karyawan senantiasa mendengarkan dengan sungguh-sungguh keluhan, saran peserta didik. Guru melibatkan peseta didik secara langsung sehingga berpengaruh terhadap karakter peserta didik. (4) Pengembangan nilai dan literasi moral dalam mewujudkan generasi berakhlakul karimah dilakukan SMP N 4 Purworejo untuk memberikan keterampilan berfikir kritis, kreatif, dan berkomunikasi dengan jelas. (5) Pengembangan program pendidikan nilai untuk mewujudkan generasi berahlakul karimah yang dilakukan SMP N 4 Purworejo yaitu dengan memasukkan dalam pembelajaran ekstra kurikuler.
\end{abstract}

Kata kunci: Manajemen, Pendidikan Karakter, Akhlakul Karimah

\section{PENDAHULUAN}

Pendidikan Nasional bertujuan untuk berkembangnya potensi peserta didik agar menjadi manusia yang beriman dan bertaqwa kepada Tuhan Yang Maha Esa, berakhlak mulia, sehat, berilmu, cakap, kreatif, mandiri dan menjadi warga negara yang demokratis serta bertanggung jawab. Sedangkan pendidikan nasional berfungsi mengembangkan kemampuan dan membentuk watak serta peradaban bangsa yang bermartabat dalam rangka mencerdaskan kehidupan bangsa.

Abad 21 merupakan tantangan besar yang menuntut respon tepat dan menyeluruh terhadap pendidikan Islam. Pendidikan merupakan wahana yang sangat strategis dan efektif dalam menciptakan manusia-manusia berkualitas dan berkepribadian. Pribadipribadi yang berkualitas inilah yang mampu melakukan perubahan-perubahan positif. 
Selama ini pembelajaran di sekolah lebih banyak menekan pada pencapaian kemampuan atau keahlian bidang keilmuannya (hard skills), sedang aspek afektif (soft skills) hanyalah sebagai sisipan apabila guru yang bersangkutan menyadari pentingnya aspek ini . Kegiatan di sekolah perlu pembiasaan- pembiasaan. Salah satunya adalah pembiasaan untuk melakukan salat berjama'ah zuhur di sekolah dan lain sebagainya. Harapannya dengan kegiatan ini mampu membentuk perilaku mulia, terbangun 18 karakter siswa. Terbentuknya karakter yang baik bagi siswanya.

Ada 4 pilar kebangsaan sebagai dasar pembangunan karakter bangsa adalah (1) Pancasila, (2) Undang-undang Dasar 1945. (3) Bhinneka Tunggal Ika (4) Negara kesatuan Republik Indonesia. Artinya Pendidikan karakter bangsa adalah upaya mewujudkan karakter bangsa yang mengejawantahkan nilai yang terkandung dalam empat pilar tersebut. ${ }^{106}$

Pendidikan Islam secara ideal seharusnya menciptakan manusia yang unggul secara intelektual, kaya dalam kebijakan, visioner, anggun dalam moral dan akhlak serta harus mampu survive di tengah persaingan global yang semakin tajam, bahkan harus mampu tampil ke depan, mampu berkompetisi, berwatak dinamis memiliki kreativitas bermutu serta mampu memenuhi tuntutan kebutuhan masyarakat.

Sepanjang sejarah pendidikan selalu dimaksudkan untuk mempersiapkan peserta didik atau generasi muda agar dapat melaksanakan hidup dan kehidupanya di masa depan. Pendidikan akan membantu agar manusia lebih manusiawi. Semakin tinggi tingkat pendidikan, maka seharusnya menjadi semakin terdidik dan semakin manusiawi ditunjukkan oleh pada tingkah lakunya.

Pendidikan dalam Islam adalah membina manusia baik dalam pribadi ataupun kelompok sehingga mampu menjalankan fungsinya sebagai hamba Allah selaku KhalifahNya (Surat Al Baqoroh ayat 30), guna membangun dunia memajukan, memakmurkan sesuai al Qur'an surat Hud ayat 61:

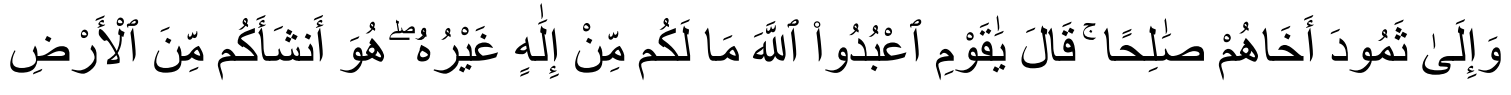

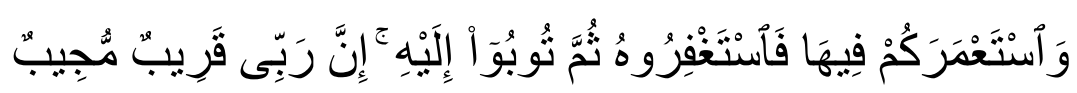

Dan kepada kaum Samud (Kami utus) saudara mereka, Saleh. Dia berkata, "Wahai kaumku! Sembahlah Allah, tidak ada Tuhan bagimu selain Dia. Dia telah menciptakanmu dari bumi (tanah) dan menjadikanmu pemakmurnya, karena itu mohonlah ampunan kepada-Nya. Sesungguhnya Tuhanku sangat dekat (rahmat-Nya) dan memperkenankan (doa hamba-Nya)."

\footnotetext{
106 Kementerian Pendidikan dan Kebudayaan, Pedoman Pembinaan Pendidikan Akhlak Mulia Siswa Melalui Pengembangan Budaya Sekolah, (Jakarta: Dirjen Pendidikan Dasar, 2012), hlm. 2.
} 
Era globalisasi yang ditandai dengan semakin berkembangnya ilmu pengetahuan dan teknologi, terlebih teknologi informasi seperti komputer . Dan internet sebagai akibat cepatnya perubahan sosial. Hal ini merupakan sunatullah, yang tidak bisa dielakkan. Perubahan era yang begitu cepat menuntut manusia dan institusi pendidikan serta penyelenggara pendidikan untuk menyiapkan bekal, menuntut penyesuaian diri dan pembenahan seperlunya agar mampu berkompetisi. Dengan demikian diharapkan institusi dapat tetap eksis bahkan mampu berkembang memperoleh kemajuan.

Sangat diperlukan kesiapan-kesiapan yang serius di segenap perangkat sekolah, misalnya dari tenaga kependidikan, media dan sarana prasarana, buku-buku panduan, perpustakaan, komputer, juga tentang pendekatan dan metode yang tepat serta variatif sehingga mampu menghasilkan output belajar yang mencerminkan mutu lembaga secara maksimal. Mampu membentuk karakter-karakter yang baik.

Perencanaan terjadi di semua tipe kegiatan. Perencanaan adalah proses dasar dimana manajemen memutuskan tujuan dan cara mencapainya. ${ }^{107}$ Untuk itu sekolah dituntttut untuk berani melakukan inovasi kreatif dengan senantiasa mencermati, melakukan analisis baik lingkungan internal maupun lingkungan eksternal Sekolah yang minimal berdampak pada munculnya ide-ide kreatif dan inovatif terbaiknya menuju pada kemajuan sekolah serta bermanfaat bagi masyarakat.

Lembaga pendidikan tinggi diarahkan kepada research university orientasi program ke arah penelitian menuntut berbagai penyesuaian terhadap berbagai kebijakan. ${ }^{108}$ Mau tidak mau pendidikan sudah menjadi industri. Sebagai suatu industri pengembangan (sumber daya) manusia, pendidikan harus dikelola secara professional, sehingga mampu memasok tenaga terampil sesuai kebutuhan masyarakat dan menjawab tuntutan global serta adanya relevansi dengan dunia kerja. ${ }^{109}$ Orang tua yang menyekolahkan anaknya paling tidak sebagian dapat dilihat hubunganya dengan pemikiran bahwa persekolahan merupakan suatu investasi karena akan menghasilkan suatu rate of return berdasarkan biayanya yang relative langsung pada benefits yang akan diraih pada masa yang akan datang dalam income yang lebih tinggi bagi anak yang terdidik. ${ }^{110}$

Hal yang sangat diperlukan untuk mensikapi masalah ini adalah visi, misi, dan tujuan yang jelas. Menurut Ginanjar Kartasasmita, visi masyarakat Indonesia di tahun 2018 antara lain (1) manusia Indonesia yang telah berpendidikan lebih tinggi, lebih sehat, pengetahuan umumnya lebih luas,... makin cerdas manusia dan pekerjaanya makin

\footnotetext{
${ }^{107}$ Handoko, Hani, Manajemen, (Yogyakarta: BPFE, 2003), hlm. 77.

108 Tilaar, H.A.R, Manajemen Pendidikan Nasional Kajian Pendidikan Masa Depan, (Bandung: Remaja Rosda Karya, 2003), hlm. 97.

109 Ibid, hlm. 153.

${ }^{110}$ Sufyarma, Kapita Selekta Manajemen Pendidikan, (Bandung: Alfabeta, 2003), hlm. 28.
} 
canggih, makin berdisiplin dengan interaksi yang makin intensif dengan dunia internasional, dan (2) kualitas demokrasi meningkat kehidupan masyarakat yang trasparan, berkembangnya sikap pembaharuan dan kritis masyarakat. ${ }^{111}$ Sekolah yang notabene mencetak SDM yang berkualitas yaitu dibuktikan dengan penguasaan pengetahuan, ketrampilan, keahlian serta wawasan yang sesuai dengan perkembangan IPTEK, harus menjadi pilot, barisan terdepan dalam mewujudkan visi tersebut. Oleh karena itu pengelolaan dituntut professional, manajemen kepemimpinan, sumber daya manusia sebagai tenaga kependidikan, pelayanan, proses belajar mengajar dan sarana prasarana pendidikan mutlak harus dikembangkan.

Sekolah tentunya memiliki visi. Visi tersebut dapat diterjemahkan dalam indikator yang jelas, dapat dipahami dan dilaksanakan oleh segenap elemen/ perangkat yang terkait. Perlunya penerapan manajemen professional sehingga pada setiap elemen dapat bekerja melaksanakan tugasnya sesuai dengan sistem dan aturan yang tepat disepakati. Pola manajemen personal yang jelas membuktikan bahwa sebuah institusi pendidikan menjadi tidak jalan, tidak mampu bersaing, serta sangat tergantung pada figur seseorang segera harus ditinggalkan.

Berkait dengan otonomi daerah di bidang pendidikan, menurut Mantja bahwa desentralisasi mengandung makna pendelegasian wewenang, baik itu menyeluruh ataupun sebagian, maka desentralisasi sebagian atau seluruh wewenang. Pendelegasian itu berarti penyerahan wewenang dari pusat ke daerah, atau dari pemerintah pusat kepemerintah daerah atau dari unit ke unit di bawahnya termasuk pula dari pemerintah ke masyarakat. ${ }^{112}$ Desentralisasi pendidikan akan mendorong terciptanya kemandirian, semakin memberikan peluang lebar bagi partisipasi masyarakat sebagai salah satu modal di dalam pengembangan sekolah sehingga pada giliranya peningkatan pelayanan pendidikan bagi masyarakat. Selain itu desentralisasi pendidikan membuka peluang bagi sekolah untuk melakukan inovasi sehingga sekolah memiliki kelebihan yang dapat ditonjolkan.

Dalam pengembangan memunculkan ide-ide yang kreatif, dan inovatif terbaiknya menuju pada kemajuan, atau setidaknya membangkitkan motivasi penyelenggara untuk bekerja lebih produktif, memiliki wawasan ke depan/ visioner, yang pada akhirnya bermuara para kualitas lulusan dan kemajuan sekolah

Pendidikan yang berkualitas niscaya menuntut biaya yang tergolong mahal/tinggi. ${ }^{113}$ Hal ini harus menjadi pertimbangan bagi pengelola, hubunganya dengan desentralisasi pendidikan.

\footnotetext{
111 Ibid, hlm. 31.

112 Ibid, hlm. 84.

113 Ibid, hlm. 37.
} 
Berikutnya untuk mampu menghasilkan lulusan yang berkualitas tentunya membutuhkan pengelola dengan sumber daya manusia yang berkualitas serta manajemen kepemimpinan yang berkualitas pula. SDM merupakan pelaku utama dalam organisasi. Karenanya harus memenuhi kualifikasi yang dibutuhkan.

Buku Putih Komisi Eropa tentang Growth, Competition and Employment, menjelaskan bahwa dalam menghadapi tantangan abad 21 adalah amat penting melakukan upaya secara besar-besaran di bidang pendidikan, khususnya pelatihan untuk membelajarkan masyarakat supaya memiliki kemampuan bersaing dalam era globalisasi melalui penguasaan pengetahuan dan keterampilan baru sesuai dengan kebutuhan masyarakat, bangsa dan kehidupan global. ${ }^{114}$ Karenanya SDM dituntut untuk memperkaya pengetahuan dan keilmuanya melalui pendidikan dan pelatihan. Selain itu dituntut memiliki krakter yang baik. Untuk itu sekolah harus mempersiapkan diri, mampu mencetak anak-anak yang memiliki pengetahuan luas dan berkarakter mulia.

Gambaran tentang SMP Negeri 4 Purworejo. Sekolah ini termasuk sekolah favorit pilihan masyarakat. Secara akademik nilai rata- rata siswa yang masuk ke sekolah ini tergolong tinggi. Posisi sekolah juga sangat strategis di tengah kota. Sarana prasarana sekolah meskipun belum sempurna namun sudah cukup representatif dalam mendukung proses belajar anak. Melihat hal itu di satu sisi terdapat kemudahan berbagai akses, disisi lain perlu dibangun pendidikan karakter yang baik sehingga mampu membentuk generasi yang berakhlakul karimah. Di sekolah tempat penelitian ini (di SMP Negeri 04 Purworejo) sudah dilakukan pendidikan karakter, namun demikian masih butuh optimalisasi dan penambahan kuantitas program. Dengan melihat visi sekolah yaitu "mewujudkan lulusan yang cerdas, santun, taqwa, inovatif, kompetitif, berprestasi, peduli dan berbudaya lingkungan" sudah tercermin bahwa sekolah ini memperhatikan pendidikan karakter anak. Oleh karena itu, penulis tertarik untuk meneliti lebih lanjut mengenai Manajemen Pendidikan Karakter dalam Mewujudkan Generasi Berakhlakul Karimah di SMP Negeri 04 Purworejo.

\section{KAJIAN LITERATUR}

\section{Manajemen Pendidikan Karakter}

Pendidikan karakter kini memang menjadi isu utama pendidikan, selain menjadi bagian dari proses pembentukan akhlak anak bangsa, pendidikan karakter ini pun diharapkan mampu menjadi pondasi utama dalam mensukseskan Indonesia Emas 2025. Di lingkungan Kemdiknas sendiri, pendidikan karakter menjadi fokus pendidikan di seluruh jenjang pendidikan yang dibinannya.

Proses pendidikan karakter di suatu sekolah tercermin dari visi dan misinya yang memiliki tujuan membentuk karakter bagi seluruh warga sekolah. Visi misi tersebut

\footnotetext{
${ }^{114}$ Sudjana, HD, Manajemen Program Pendidikan Untuk Pendidikan Non Formal dan Pengembangan SDM, (Bandung: Falah Production, 2004), hlm. 399.
} 
selanjutnya menjadi budaya sekolah. Faktor yang paling penting dalam kegiatan menggerakkan orang lain untuk menjalankan kegiatan manajemen adalah kepemimpinan. Kepemimpinan (leadership\} berbeda dengan pemimpin (leader). Kepemimpinan adalah kemampuan untuk mempengaruhi perilaku seseorang atau kelompok untuk mencapai suatu tujuan atau karena alasan lain. ${ }^{115}$ Dengan demikian, maka dapat diketahui bahwa kepala sekolah sebagai pemimpin sekolah memiliki peran besar dalam pembentukan karakter siswa.

Untuk menumbuhkan karakter yang baik dapat diajarkan melalui pendidikan karakter, adalah upaya yang dilakukan dengan sengaja untuk untuk mengembangkan karakter yang baik berdasarkan kebajikan-kebajikan inti yang secara obyektif baik individu maupun masyarakat. Kebajikan inri meliputi dua kebajikan yaitu kebajikan fundamental dan kebajikan esensial. Kebajikan fundamental ada dua kebajikan yang kan ditumbuhkan yaitu rasa hormat dan tanggung jawab., sedangkan kebajikan esensial ada sepuluh yaitu kebijaksanaan, keadilan, ketabahan, pengendalian diri, kasih, sikap positif, kerja keras, integritas, penuh syukur dan kerendahan hati. Agar sekolah dapat berhasil menumbuhkan nilai nilai kebajikan tersebut, maka sekolah dalam proses pengajarannya dengan mendasarkan pengatahuan moral, perasaan moral dan tindakan moral dimana semua unsur disekolah akan ikut terlibat.

Agar pembelajaran berkarakter dapat dilaksanakan maka perlu diorganisir. Setidaknya terdapat lima hal yang perlu diperhatikan berkaitan dengan organisasi pembelajaran dalam implementasi pendidikan karakter di sekolah yaitu pelaksanaaan pembelajaran, pengadaan, pembinaan tenaga ahli, pendayagunaan lingkungan dan sumber daya masyarakat, pengembangan, dan penataan kebijakan serta keterbatasan pembelajaran. ${ }^{116}$ Diperlukan penerapan fungsi-fungsi manajemen dalam penerapan pendidikan karakter.

Pembentukan kepribadian seseorang diarahkan untuk meningkatkan dan atau mengembangkan potensi atau faktor dasar (bawaan) melalui proses pendidikan yang berpedoman pada nilai-nilai karakter. Melalui pembiasaan, pelatihan, dan pembimbingan diharapkan karakter seseorang akan menjadi lebih baik. ${ }^{117}$ Memang perlu ketelatenan dan keteladanan untuk itu. Peningkatan potensi tersebut meliputi tiga hal, yaitu mencakup aspek IQ, EQ, dan SQ. Banyak metode yang dapat dilakukan dalam pendidikan karakter, antara lain seperti keteladanan guru, orang tua, dan masyarakat.

\footnotetext{
$115 \mathrm{Ibid}, \mathrm{hlm} .19$.

${ }^{116}$ Mulyasa, Manajemen Pendidikan Karakter, (Jakarta: Bumi Aksara, 2018), hlm. 144.

${ }^{117}$ Eliyanto. Pendidikan Aqidah Akhlak. (Yogyakarta: Prodi MPI FITK UIN Sunan Kalijaga Yogyakarta, 2017).
} 
Setiap individu pasti memiliki karakteristik yang berbeda satu sama lain. Karakteristik atau ciri khas tersebut pada dasarnya sudah dimiliki sejak lahir (gawan bayi). Begitu juga potensi berupa bakat, antara satu orang dengan orang lainnya tentu tidak semuanya sama. Selanjutnya, potensi juga dapat berupa aspek jasmani (fisik seseorang, warna kulit, tinggi, pendek) dan rohani (bakat, mental, karakter, emosi, kecerdasan) tidak semua orang sama. Perbedaan bukanlah masalah, perbedaan adalah rahmat. Tiada orang yang sempurna, oleh karena itu, solusinya yaitu saling bekerja sama untuk melengkapi hidup satu sama lain. Jangan saling hina. Orang hina adalah orang yang suka menghina. Kompetisi / persaingan hidup tidak lebih baik dari menjaga kebersamaan / kerukunan dan saling bekerja sama mewujudkan visi bersama. Pendidikan Islam yang sesungguhnya adalah diarahkan pada yang demikian itu.

Menurut Howard Kirschenbaum, cara untuk meningkatkan nilai dan moralitas (karakter/akhlak mulia) di sekolah dapat dikelompokkan ke dalam lima metode, yaitu:

a. Inculcating values and morality (penanaman nilai-nilai dan moralotas);

b. Modeling values and morality (pemodelan nilai-nilai dan moralitas);

c. Facilitating values and morality (memfasilitasi nilai-nilai dan moralitas);

d. Skills for value development and moral literacy (keterampilan untuk pengembangan nilai dan literasi moral); dan

e. Developing a values education program (mengembangkan program pendidikan nilai). ${ }^{118}$

Dari pendapat tersebut, maka dapat diketahui bahwa semua guru harus meningkatkan kualitas pembelajaran di sekolah. Salah satu upaya yang dapat dilakukan adalah pembinaan karakter siswa melalui proses pembelajaran di kelas dan juga membangun lingkungan yang kondusif di luar kelas. Metode di atas termasuk dalam pendekatan komprehensif.

\section{Akhlakul Karimah}

Akhlak baik yaitu akhlak yang tidak bertentangan dengan ajaran Al Qur'an dan Al Hadits. ${ }^{119}$ Akhlak baik atau akhlak terpuji harus didasarkan pada keimanan. Perbuatan yang secara lahiriyah baik, namun tidak didasari iman, maka tidak mendapat pahala. Allah memerintahkan kepada setiap muslim untuk berbuat baik.

Dengan berakhlak baik, kita akan lebih merasa dekat dan kemudian cinta kepada Allah SWT. Akhlak baik akan menguntungkan. Dengan berakhlak baik, kita akan memperoleh kebahagiaan hidup (di dunia dan di akhirat).

Akhlak yang baik itu sudah seharusnya menjadi kebiasaan dalam diri seseong. Iman Al Ghazali dalam Ihya Ulumudin bahwa ahlak adalah daya kekuatan (sifat) yang tertanam dalam jiwa yang mendorong perbuatan-perbuatan yang spontan tanpa

\footnotetext{
${ }^{118}$ Darmiyati Zuchdi, Pendidikan Karakter Konsep Dasar dan Implementasi di Perguruan Tinggi, (Yogyakarta: UNY Pres, 2015), hlm. 24.

${ }^{119}$ Eliyanto, Op.Cit.
} 
melakukan pertimbangan pikiran. Jadi akhlak merupakan sikap yang melekat pada diri seseorang dan secara spontan diwujudkan dalam tingkah laku dan perbuatan. Artinya bahwa jika seorang atau peserta didik sudah memiliki akhlak yang baik maka tindakan spontanitas yang muncul juga akan baik, umpamanya dalam penggunaan kalimah toyyibah secara spontan. Akhlakul karimah sangat penting untuk dipraktikkan dan dibiasakan sejak dini oleh siswa dalam kehidupan sehari-hari. Terutama dalam rangka mengantisipasi dampak negatif era globalisasi dan krisis multidimensional.

Dengan demikian, diperlukan generasi muda yang berakhlakul karimah untuk mewujudkan bangsa yang maju. Untuk mewujudkan generasi yang berakhlakul karimah, sekolah perlu menciptakan suasana sekolah yang dinamis, selalu menuju kepada keadaan yang lebih baik dari sebelumnya, dan mengupayakan budaya sekolah yang religius. Pemerintah dengan melibatkan stakeholder memfasilitasi serta promosi pimpinan sekaligus memberikan dorongan dan kesempatan kepada sekolah untuk selalu meningkatkan kemampuan sumber daya manusia dengan tidak segan-segan melakukan pengiriman para pemimpin universitas, guru untuk studi banding di luar negeri. Bahkan kalau perlu diteruskan dengan perwakilan mahasiswanya Hal ini dilaksanakan untuk memperbaiki keadaan yang ada sekarang.

\section{METODE PENELITIAN}

Jenis penelitian ini yaitu kualitatif, pendekatan yang lebih menekankan pada aspek pemahaman secara mendalam terhadap suatu masalah manusia dan sosial. Waktu penelitian adalah antara 1 April 2019 sampai dengan 1 September 2019, dan tempat penelitian adalah di SMP Negeri 04 Purworejo.

Subjek dan informan penelitian ini yaitu orang-orang yang berhubungan dengan manajemen pendidikan karakter dalam mewujudkan generasi berakhlakul karimah, yaitu: kepala sekolah, guru, karyawan, komite sekolah dan siswa dan komponen lainya yang terlibat dalam stuktur organisasi di SMP Negeri 04 Purworejo.

Teknik pengumpulan data merupakan cara yang digunakan peneliti untuk memperoleh data penelitian yang dibutuhkan. Proses pengumpulan data dalam penelitian ini dilakukan dengan: observasi, wawancara mendalam, dan dokumentasi.

Dalam menguji keabsahan data peneliti menggunakan tehnik Triangulasi, yakni teknik pemeriksaan keabsahan data yang memanfaatkan sesuatu yang lain diluar data untuk keperluan pengecekan atau sebagai pembanding terhadap data itu.Itu artinya melakukan validasi, dengan cara mengecek dokumen program dan bukti tertulis lainnya. ${ }^{120}$ Dalam penelitian ini menggunakan Triangulasi metode yaitu menggunakan dua strategi yaitu: (1) Pengecekan terhadap derajat kepercayaan penemuan hasil penelitian

\footnotetext{
${ }^{120}$ Patton, Michael Quinn. Metode Evaluasi Kualitatif. (Yogyakarta: Pustaka Pelajar, 2006), hal. 280.
} 
dengan beberapa tehnik pengumpulan data; (2) Pengecekan derajat kepercayaan beberapa sumber data dengan metode yang sama.

Langkah-langkah yang dilakukan penulis lakukan untuk menganalisis data yang sudah diperoleh dari hasil observasi, wawancara, dan dokumentasi yaitu dengan menggunakan model analisis data Miles dan Huberman sebagaimana yang dikutip oleh Sugiyono, yaitu reduksi data (data reduction), penyajian data (data display), dan penarikan kesimpulan (conclusion drawing/verification). ${ }^{121}$

\section{HASIL PENELITIAN DAN PEMBAHASAN}

\section{Penanaman Nilai-Nilai dan Moralitas dalam Mewujudkan Generasi Berakhlakul Karimah di SMP Negeri 4 Purworejo}

Penanaman nilai-nilai karakter merupakan tahapan yang sangat penting dalam program pendidikan karakter. Hasil dari pembahasan mengenai nilai-nilai karakter, nantinya dijadikan sebagai arahan dalam proses penanaman karakter pada peserta didik sehingga dapat mencapai tujuan dari pendidikan karakter yang diinginkan.

Penanaman nilai-nilai dan moralitas dalam mewujudkan generasi berakhlakul karimah di SMP Negeri 4 Purworejo. dilakukan oleh kepala sekolah, guru dan karyawan dan seluruh warga sekolah. Guru mengintegrasikan karakter melalui RPP pembelajaran dan melalui kegiatan ektra kurikuler sekolah, pemberian motivasi.

Penanaman karakter pada peserta didik SMP Negeri 4 Purworejo, selain melalui kegiatan pembiasaan, keteladanan, dan pembinaan,juga diintegrasikan kedalam kegiatan pembelajaran seluruh muatan pelajaran. Setiap rencana pelaksanaan pembelajaran yang disusun oleh setiap guru harus mengintegrasikan nilai-nilai karakter tersebut didalamnya.

Hal tersebut senada dengan pendapat Darmiyati Zuchdi, bahwa pendidikan karakter di madrasah yang dilaksanakan melalui berbagai program. Ada banyak nilai karakter atau akhlak mulia yang harus diimplementasikan dalam kehidupan seharihari. $^{122}$

Penetapan nilai-nilai karakter yang positif yang akan ditanamkan bisa dilakukan melalui rapat bersama dengan komite madrasah dan pihak yayasan (jika itu sekolah swasta), sehingga nilai-nilai yang akan dikembangkan benar-benar bisa dijadikan sebagai pedoman bagi para guru dan warga madrasah lainya dalam membangun karakter peserta didik secara efektif dan efesien.

\section{Pemodelan Nilai-Nilai dan Moralitas Dalam Mewujudkan Generasi Berakhlakul} Karimah di SMP Negeri 4 Purworejo

Model pengajaran merupakan gambaran suatu lingkungan pembelajaran. Didalamnya tercakup perilaku guru dan siswa pada saat model tersebut diterapkan. Model pendidikan nilai moral yang dapat dilaksanakan di SMP Negeri 4 Purworejo

\footnotetext{
${ }^{121}$ Sugiyono, Metode Penelitian Pendidikan, (Bandung: Alfabeta. 2009), hal. 254.

122 Darmiyati Zuchdi, Op.Cit. hlm. 25.
} 
berbeda antara guru yang satu dengan yang lain, tetapi juga ada yang sama. Pada intinya model-model tersebut adalah cara untuk mengatasi masalah dalam pendidikan karakter dan untuk mencapai pendidikan karakter.

Pernyataan tersebut di atas sesuai dengan pendapat Darmiyati Zuchdi, yang menyatakan bahwa perbedaan gaya mengajar sebetulnya disebabkan oleh penggunaan model pengajaran yang berbeda. Demikian pula persamaan gaya mengajar juga disebabkan oleh penggunaan model pengajaran yang sama. ${ }^{123}$

Tentang Pemodelan Nilai-Nilai dan Moralitas Dalam Mewujudkan Generasi Berakhlakul Karimah kepala sekolah semua guru dan karyawan serta orang tua menyadari bahwa perilakunya menjadi model bagi anak didiknya. Peserta didik tidak mengambil model perilaku dari tokoh atau artis. Oleh karena itu semua warga sekolah senantiasa berhati hati dalam bertingkah laku dan bertutur kata dihadapan Peserta didik di sekolah.

Dalam pendidikan nilai dan spiritualitas, pemodelan atau pemberian teladan merupakan strategi yang biasa digunakan. Pemodelan penting dalam memberikan pembelajaran kepada siswa tanpa harus melalui banyak nasihat. Melalui pemodelan, siswa benar-benar mampu melihat dan merasakan pengalaman yang menjadikannya terbiasa dengan hal-hal yang baik di lingkungan sekitarnya. Untuk dapat menggunakan strategi ini, ada dua syarat yang harus dipenuhi. Pertama, guru atau orang tua harus berperan sebagai model yang baik bagi murid-murid atau anak-anaknya. Kedua, anakanak harus meneladani orang-orang yang berakhlak mulia.

\section{Memfasilitasi nilai-nilai dan moralitas dalam mewujudkan generasi berakhlakul} karimah di SMP Negeri 4 Purworejo

Dalam mewujudkan generasi berakhlakul karimah di SMP Negeri 4 Purworejo tentunya sekolah harus memfasilitasi nilai-nilai dan moralitas dalam mewujudkan generasi berakhlakul karimah hal yang dilakukan ialah dengan peserta didik diberikan kesempatan untuk mengatasi masalah berkaitan dengan kegiatan sekoalah. Ketika terjadi masalah yang berkaitan denga kegiatan sekolah peserta didik diberikan kesempatan untuk mengatasinya dengan baik dengan melalukan diskusi bersama.

Selain itu guru mendengarkan dengan sungguh sungguh keluhan, saran, uneguneg peserta didik. Guru karyawan mendengarkan dengan baik keluhan peserta didiknya. Guru harus memahami pikiran, perasaan peserta didik. Hal ini dilakukan dengan menyelami karakter mereka.. selain itu Guru melakukan kegiatan yang melibatkan peserta didik secara langsung sehngga memiliki motivasi berkaitan dengan nilai dan moral dalam kehidupannya. Guru menyampaikan pembanding-pembanding sikap sehingga peserta didik melakukan evaluasi diri terhadap perilakunya dengan membandingkan perilakunya dengan perilaku baik dari orang lain.

${ }^{123} \mathrm{Ibid}, \mathrm{hlm} .29$. 


\section{Keterampilan untuk pengembangan nilai dan literasi moral dalam mewujudkan} generasi berakhlakul karimah di SMP Negeri 4 Purworejo

Untuk pengembangan nilai dan literasi moral dalam mewujudkan generasi berakhlakul karimah diperlukan suatu keterampilan dengan cara berfikir kritis. Jika ada pertanyaan atau pernyataan guru tentang sesuatu hal yang menurut saudara kurang jelas peserta didik Meminta penjelasan ulang pada guru yang bersangkutan , Jika melakukan sesuatu hal maka ia berpikir tentang alasan melakukan hal tersebut. Kemudian apabila ada informasi terkait dengan kegiatan sekolah peserta didik mencari informasi agar informasi yang diterima adalah informasi yang benar kepada guru atau pihak yang terkait dengan informasi itu.

Ketrampilan lain yang dimiliki peseerta didik dalam mengembangkan nilai dan moralitas adalah peserta didik memiliki ketrampilan berfikir kreatif., peseerta didik mampu menemukan cara baru untuk memecahkan/ menyelesaikan soal yang di sajikan guru. Dan berusaha menyelesaikannya dengan baik

Selain itu peserta didik memiliki kerampilan berkomunikasi dengan jelas. Ia melalukan presentasi di kelas. Kemudian presentasi yang dilakukan menurut siiswa lain dapat dipahami. Peserta didik juaga melakukan komunikasi melalui medsos terutama jika meraka memiliki kuota internet.

Kemudian terkait dengan keaktifanmengisi tulisan atau gambar di papan majalah sebagian responden tidak aktif melakukannya. Namun dari observasi penulis Disekolah disediakan majalah dinding kondisinya ada dan baik. Meskipun mungkin tidak semua peserta didik terlibat langsung dalam pembuatan tulisan atau gambar di majalah dinding. Hanya peserta didik tertentu yang malakukannya sedang peserta didik lain haya membantunmya.

Untuk pengembangan nilai dan literasi moral dalam mewujudkan generasi berakhlakul karimah juga diperlukan adanya Peserta didik yang memiliki ketrampilan menyimak. Dari wawancara dengan peserta didik ketika guru menyampaikan materi pelajaran peserta didik kadang kadang berbincang-bincang dengan temannya. Namun peserta didik juga mampu pernah membuat tulisan berdasarrkan penjelasan guru, mendengarkan penjelasa guru dan melaksanakan perintahnya.

Ketrampilan lain yang dimiliki peserta didik SMP Negeri 4 Purworejo adalah tentang ketrampilan asertif/ mengemukakan pendapat secara terbuka. Peserta didik pernah berpidato, tampil didepan umum, aktif melaksanakan diskusi terutama pada ssat pembelajaran yang menggunakan metode diskusi.

Kemudian tentang ketrampilan peserta didik dalam mengatasi ancaman teman. Menurut keterangan Kurnia Primaningsih, ia tidak pernah marasa diancam oleh temannya, namun jika ada masalah dengan temannya ia membicarakanya dengan teman, atau guru tertentu. Peserta didik memiliki ketrampilan mengatasi konfliknya dengan membicarakan dengan teman secara baik - baik 


\section{Mengembangkan program pendidikan nilai dalam mewujudkan generasi berakhlakul} karimah di SMP Negeri 4 Purworejo

Visi, misi dan tujuan akan terwujud jika telah melaksanakan langkah langkah strategis sebagai usaha pengembangan. Pengembangan ini bisa dalam arti kuantitas. Lebih dari itu pembangunan fasilitas-fasilitas strategis pun terus diusahakan. Terasa tidak pernah sepi peserta didik yang melalukan kegiatan di sekolah.

Hasil wawancara menunjukkan bahwa visi misi dan tujuan SMP Negeri 4 Purworejo banyak dipahami oleh segenap komponen yang ada, mulai dari kepala sekolah guru, karyawan maupun peserta didik. Ini membuktikan bahwa sosialisasi terhadap visi misi cukup baik dan efektif, ujunya dengan pemasangan papan yang berisi visi misi ditempat yang strategis dan mudah dibaca.

Untuk memiliki kinerja yang tinggi perlu langkah yang dilakukan yaitu dengan cara :

a. Memberikan pemahaman kerpada semua personil tentang arah yang ingin dicapai/ tujuan di masa mendatang, program studi apa yang yang diinginkan ada. Dalam halini perlu duduk bersama sehingga sampai masalah teknis yang mendetail pun akan dikuasai semua personil sesuai wewenang dan tanggung jawabnya masingmasing.

b. Menjadikan tenaga - tenaga / personil yang ada menjadi lebih berpengetahuan dan memiliki keterampilan yang tinggi, inovatif dan bersemangat wirausaha. Menanggapi tuntutan ini para pemegang kebijakan di kampus jangan segan segan membiayai persinil yang ada agar menambah jenjang pendidikan mereka, melakukan pelatihan- pelatihan, diskusi dan jangan segan segan mencoba hal- hal baru termasuk pemutahiran ilmu pengetahuan. Perekrutan Personil baru yang sesuai criteria dan aturan tidak boleh alergi.

c. Masalah Finansial. Orang bekerja disamping sebuah tanggung jawab dan amanat mereka membutuhkan uang untuk keperluan dirinya, istrinya, anaknya dan keluarganya. Untuk memberikan jaminan financial pada semua pelaksana harus ada masukan financial ke kampus. Masalah financial haruslah matang dan jelasm perlu memperhatikan resioko terkecil, pendeknya harus terencana matang dan realistis. Gaji yang cukup bias menjadikan semangat dalan memberikan layanan. Ditambah dengan filosofi Ngewongke wong juga bisa menjadikan nilai keistimewaan tersendiri Aturan yang jelas, kebersamaan dan kekeluargaan juga sangat perlu dibangun, diciptakan, diprioritaskan dalam usaha peningkatan mutu layanan. Untuk mendapatkan masukan financial harus diusahakan tidak hanya mutlak bersumber dari peserta didik. Akan tetapi menurut hemat penulis bisa juga dari bantuan 
donator baik dari pemerintah atau stake holder lainnya/ swasta. Alangkah idealnya jika sekolah memiliki berbagai usaha layanan sebagai komponen pendapatan sekolah. Baik berupa layanan umum maupun layanan peserta didik.

\section{Kepemimpinan dalam Pengembangan Program}

Dalam hal kepemimpinan sebagai dasar dalam al Quran surat al Ahzab ayat 21

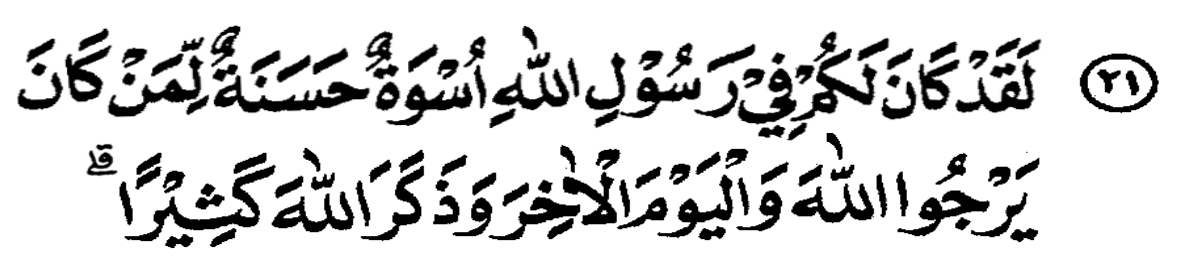

Artinya sesungguhnya telah ada pada diri rasulullah suri tauladan yang baik. ${ }^{124}$

Kenyataan sejarah Rasulullah bukanlah seorang khalifah sebagaimana pemerintahan selanjutnya, terlebih seperti pemerintahan kehalifahan umayyah dan kekhalifahan Abbasiyah, akan tetapi karena rosullullah mengetahui betul, memahami betul hal - hal yang detail sekalipun, rasulullah memberilah uswah keteladanan yang baik maka kebesaran kepemimpinan beliau sangat tertanam pada diri sahabatnya, pengikutnya saat itu. Sehingga hasilnya pada generasi berikutnya berkat kepemimpinan yang demikuan organisasi dapat terus berkembang. Meskipun rasullullah sudah meninggal sekalipun.

Ilustrasi diatas dapat menjadikan motivasi pimpinan dalam memberikan pelayanannya. Demi tercapainya tujuan organisasi. Pengembangkan program pendidikan nilai dalam mewujudkan generasi berakhlakul karimah di SMP Negeri 4 Purworejo Tentunya sekolah merencanakan program pendidikan nilai untuk mewujudkan generasi berahlakul karimah.yaitu drngan memasukkan dalam pembelajaran ekstra kurikuler. Selain itu proram yang dilakukan disekolah. Terkait dengan karakter dari obserfasi penulis peserta didik secara spontan berjabat tangan meskipun dengan orang yang masuk ke lingkungan sekolah yang belum dikenal. Budaya $5 \mathrm{~S}$ ( senyum salam sapa sopan santun ) juga tampak dilakukan. Ada responden yang mengatakan budaya $4 \mathrm{~S}$. Kemudian dikelas setiap memulai pelajaran pertama ada hormat bendera salam abita ( Abita Abita Aku Bangga Indonesia Tanah Airku Merah Putih Ya ) dipimpin ketua kelas selanjutnya menyanyikan lagu indoesia raya dari sentaral.

Ada kelas yang tidak ada bendera, perlu ditambahkan salam PPK ( Cerdas Berkarakter Menyenangkan Luar Biasa Hebat ). Pembiasaan lain yang dilakukan di SMP Negeri 4 Purworejo adalah pembiasaan salat dhuha, salat dhuhur berjamaah dan program literasi sekolah. Terkait dengan program literasi menurut hemat penulis perlu

${ }^{124}$ Departemen Agama RI. Al Quran dan Terjemahnya. (Bandung: Diponegoro, 2008). 
adanya penguatan mengenai kontrol terhadal hasil literasi yang dilakukan oleh siswanya. Sekolah jangan hanya membebankan untuk mengecek hasil literasi semua siswa kepada guru bahasa indonesia saja, namun mungkin akan lebih ringan ketika cek hasil literasi dilakuakan oleh wali kelas atau dibantu oleh guru yang mengampu jam literasi secara langsung.

Selanjutnya salah satu kebijakan sekolah tentang program pendidikan karakter untuk mewujudkan generasi berahlakul karimah.di SMP Negeri 4 Purworejo menurut kepala sekolah salah satunya dengan memasukkan karakter dalam RPP guru. Bagaimana dengan pelaksanaan program itu menurut keterangan kepala sekolah program tersebut berjalan dengan baik dan didukung oleh semua warga sekolah. Terkait hal ini hemat penulis perlu adanya kesadaran dari semua unsur guru untuk membuar RPP yang memasukkan unsur karakter didalannya. Terutama kepada guru yang belum melakukannya secara administrasi.

Selanjutnya tentang evaluasi program pendidikan nilai untuk mewujudkan generasi berahlakul karimah. Sekolah melakukan evalusi program pada tiap akhir semester. Selanjutnya proram yang dilakukan sudah sesuai dengan program pendidian karakter. Ada hal yang perlu diperhatikan kemampuan peserta didik untuk membuat keputusan secara mandiri. Dari keterangan peserta didik la tidak selalu membuat keputisannya secara mandiri tapi pernah membuat keputusan secara mandiri. Peserta didik juga dapat menentukan tindakan moral secara tepat, meskipun kadang kadang mengakui bahwa ia melakukan pelanggaran.

\section{KESIMPULAN}

Berdasarkan analisis yang telah dipaparkan di dalam pembahasan, maka dapat ditarik kesimpulan sebagai berikut :

1. Penanaman nilai-nilai dan moralitas dalam mewujudkan generasi berakhlakul karimah di SMP Negeri 4 Purworejo dilakukan oleh kepala sekolah, guru dan karyawan dan seluruh warga sekolah. Guru mengintegrasikan karakter melalui RPP pembelajaran dan melalui kegiatan ektra kurikuler sekolah, pemberian motivasi.

2. Pemodelan Nilai-Nilai dan Moralitas dalam Mewujudkan Generasi Berakhlakul Karimah, kepala sekolah, semua guru dan karyawan serta orang tua menyadari bahwa perilakunya menjadi model bagi anak didiknya. Peserta didik tidak mengambil model perilaku dari tokoh atau artis. Oleh karena itu, semua warga sekolah senantiasa berhati hati dalam bertingkah laku dan bertutur kata dihadapan Peserta didik di sekolah.

3. SMP Negeri 4 Purworejo memfasilitasi nilai-nilai dan moralitas dalam mewujudkan generasi berakhlakul karimah. Hal yang dilakukan ialah dengan peserta didik diberikan kesempatan untuk mengatasi masalah berkaitan dengan kegiatan sekolah. Kepalalsekolah, guru, dan karyawan senantiasa mendengarkan dengan 
sungguh-sungguh keluhan, saran, uneg-uneg peserta didik. Guru melibatkan peseta didik secara langsung sehingga berpengaruh terhadap karakter peserta didik.

4. Pengembangan nilai dan literasi moral dalam mewujudkan generasi berakhlakul karimah dilakukan SMP Negeri 4 Purworejo melalui berbagai keterampilan, di antaranya dengan cara keterampilan berfikir kritis, keterampilan berfikir kreatif, kerampilan berkomunikasi dengan jelas, dan keterampilan menyimak.

5. SMP Negeri 4 Purworejo sebagi sebuah lembaga pendidikan merencanakan program pendidikan nilai untuk mewujudkan generasi berahlakul karimah, yaitu dengan memasukkan dalam pembelajaran ekstra kurikuler. Selain itu, proram yang dilakukan disekolah yaitu terkait dengan karakter. Sekolah memiliki Budaya 5 S (senyum, salam, sapa, sopan, santun). Kemudian di kelas setiap memulai pelajaran pertama ada hormat bendera salam abita ( bita Abita Aku Bangga Indonesia Tanah Airku Merah Putih Ya) dipimpin ketua kelas selanjutnya menyanyikan lagu indoesia raya dari sentral. Ada kelas yang tidak ada bendera, perlu ditambahkan salam PPK (Cerdas Berkarakter Menyenangkan Luar Biasa Hebat). Pembiasaan lain yang dilakukan di SMP Negeri 4 Purworejo adalah pembiasaan salat dhuha, salat dhuhur berjamaah dan program literasi sekolah.

\section{DAFTAR PUSTAKA}

Darmiyati Zuchdi, (2015), Pendidikan Karakter Konsep Dasar dan Implementasi di Perguruan Tinggi, Yogyakarta, UNY Pres.

Departemen Agama RI. (2008). Al Quran dan Terjemahnya. Bandung: Diponegoro.

Eliyanto. (2017). Pendidikan Aqidah Akhlak. Yogyakarta: Prodi MPI FITK UIN Sunan Kalijaga Yogyakarta.

Handoko, Hani (2003), Manajemen, Yogyakarta, BPFE

Kementerian Pendidikan dan Kebudayaan, (2012), Pedoman Pembinaan Pendidikan Akhlak Mulia Siswa Melalui Pengembangan Budaya Sekolah, Jakarta. Dirjen Pendidikan Dasar

Mulyasa (2018), Manajemen Pendidikan Karakter, Jakarta, PT Bumi Aksara

Patton, Michael Quinn, (2006), Metode Evaluasi Kualitatif, Yogyakarta: Pustaka Pelajar.

Sudjana, HD (2004), Manajemen Program Pendidikan Untuk Pendidikan Non Formal dan Pengembangan SDM, Bandung, Falah Production.

Sufyarma (2003), Kapita Selekta Manajemen Pendidikan, Bandung , CV Alfabeta

Sugiyono, 2009, Metode Penelitian Pendidikan, Bandung: Alfabeta.

Tilaar, H.A.R (2003), Manajemen Pendidikan Nasional Kajian Pendidikan Masa Depan, Bandung, PT Remaja Rosda Karya. 